INDONESIA ACCOUNTING JOURNAL

VOLUME 2, NUMBER 2, YEAR 2020

${ }^{1}$ Corresponding author

Program Studi Akuntansi

Politeknik Ubaya

Jl. Ngagel Jaya Selatan 169

Surabaya, Indonesia, 60284

E-mail: galuh.af@staff.ubaya.ac.id

Article info:

Received 8 October 2020

Accepted 10 December 2020

Available online 10 December 2020

Keywords: event study; abnormal return; trading volume activity; stock prices; Index LQ-45

JEL Classification: G11, G12, G14, G41 DOI: http://doi.org/10.32400/iaj.30579

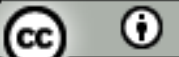

This work is licensed under a Creative

Commons Attribution 4.0

International License.

\section{Dampak pandemi Covid-19 terhadap harga saham dan aktivitas volume perdagangan (Studi kasus saham LQ-45 di Bursa Efek Indonesia)。}

Galuh Artika Febriyanti ${ }^{1}$

\begin{abstract}
The purpose of this research to examine the impact of the Covid19 on stock prices and trading volume activity on listed firms of Index LQ-45 on the Indonesia Stock Exchange. The first case of the Covid-19 in Indonesia was announced on March 2nd, 2020. This research is to find out whether there are average abnormal returns and transaction volume of the stock company listed in Index LQ-45 before and after of event the first case of the Covid19 in Indonesia was announced on March 2nd, 2020. These data have been taken for 30 days before and 30 days after the first announcement of Covid-19 in Indonesia. The result of the paired sample test shows that there is a significant difference in the abnormal return of stock company listed in index LQ-45 between before and after the first announcement of the Covid-19 case in Indonesia. This is indicated by the significance value of $0,008<$ 0,05 which the stock prices decreased after the first announcement of the Covid-19 case in Indonesia. The volume transaction also shows different significance. The transaction volume after the announcement of shares shows an increasing value.
\end{abstract}

\section{Pendahuluan}

Pasar modal Indonesia merupakan pasar yang sedang berkembang yang dalam perkembangannya sangat rentan terhadap kondisi makroekonomi secara umum serta kondisi ekonomi global dan pasar modal dunia. Pengaruh makroekonomi tidak mempengaruhi kinerja perusahaan secara seketika melainkan secara perlahan dan dalam jangka waktu yang panjang. Sebaliknya, harga saham akan terpengaruh dengan seketika oleh perubahan faktor makroekonomi tersebut karena para investor lebih cepat bereaksi. Ketika perubahan makroekonomi itu terjadi, para investor akan memperhitungkan dampaknya baik yang positif maupun yang negatif terhadap kinerja perusahaan beberapa tahun ke depan, kemudian mengambil keputusan membeli, menjual atau menahan saham yang bersangkutan. Oleh karena itu harga saham lebih cepat menyesuaikan diri terhadap perubahan variabel makroekonomi daripada kinerja perusahaan yang bersangkutan. Aktivitas paling penting yang harus diperhatikan oleh investor pada saat melakukan investasi di pasar modal yaitu pergerakan harga saham. Aktivitas pergerakan harga saham menunjukkan kinerja dari emiten. Apabila kinerja emiten semakin baik, maka keuntungan yang dihasilkan dari operasi usaha akan semakin besar. Pada kondisi ini, harga saham emiten yang bersangkutan cenderung menunjukkan kenaikan. Sebaliknya, apabila kinerja emiten memburuk, maka keuntungan yang dihasilkan dari operasi usaha akan semakin kecil. Selain harga saham, volume perdagangan saham sangat mempengaruhi jumlah saham yang beredar, jika volume perdagangan besar maka saham tersebut dinyatakan sebagai saham yang aktif. Saham yang memiliki volume perdagangan besar terjadi karena transaksi saham tersebut sangat aktif dan menarik minat banyak investor. Selanjutnya, volume perdagangan saham merupakan hal yang penting bagi seorang investor, karena volume perdagangan saham menggambarkan kondisi efek yang diperjualbelikan di pasar modal. 
Kegiatan perdagangan dalam volume yang sangat tinggi di bursa efek akan ditafsirkan sebagai tanda kondisi pasar yang baik.

Bagi investor, sebelum melakukan investasi atau penanaman modal hal terpenting adalah tingkat likuiditas suatu efek. Banyak faktor yang mempengaruhi harga saham dan volume perdagangan. Agustina dan Sumartio (2014) menemukan bahwa secara parsial, Dividend per Share (DPS) secara signifikan mempengaruhi pergerakan harga saham, sedangkan Net Profit Margin (NPM), tingkat suku bunga Sertifikat Bank Indonesia (SBI), tingkat inflasi, dan kurs valuta asing tidak berpengaruh terhadap pergerakan harga saham pada perusahaan pertambahan yang terdaftar di Bursa Efek Indonesia untuk periode 2007 sampai 2011. Toin dan Sutrisno (2015) menemukan bahwa harga saham industri perdagangan eceran di Bursa Efek Indonesia dipengaruhi secara signifikan oleh faktor internal seperti Earnings per Share (EPS) dan Return on Equity (ROE) dibandingkan faktor eksternal seperti suku bunga dan nilai kurs. Studi untuk menguji reaksi pasar terhadap suatu peristiwa (event) yang informasinya dipublikasikan sebagai suatu pengumuman disebut studi peristiwa (Hartono, 2013:623). Metode tersebut merupakan studi yang mempelajari reaksi pasar terhadap suatu peristiwa (event) yang informasinya dipublikasikan sebagai suatu pengumuman. Investor di pasar modal akan mendasarkan keputusan investasinya pada berbagai informasi yang dimilikinya dengan melihat sinyal yang diberikan oleh perusahaan, ramalan kondisi perekonomian suatu negara ataupun kejadian-kejadian lain. Event study dapat digunakan untuk menguji kandungan informasi dari suatu pengumuman dan dapat juga digunakan untuk menguji efisiensi pasar bentuk setengah kuat. Pengertian tersebut tampak bahwa sebenarnya event study dapat digunakan untuk melihat reaksi pasar modal (dengan pendekatan pergerakan harga saham) terhadap suatu peristiwa tertentu (Arde dan Kesuma, 2017). Utomo dan Herlambang (2015) menguji efek event hari libur Lebaran pada emiten yang terdaftar dalam Indeks Saham Syariah Indonesia (ISSI) menunjukkan hasil empiris terdapat average abnormal return tidak signifikan dan terdapat perbedaan average abnormal trading volume activity yang signifikan sebelum dan sesudah hari libur Idul Fitri.

Meskipun pengaruh lingkungan eksternal atau event eksternal tidak secara langsung terkait tetapi bukan berarti peristiwa tersebut tidak memiliki dampak terhadap aktivitas di pasar modal. Berbagai peristiwa seperti kondisi politik, bencana alam, peperangan, isu-isu hukum seringkali mempengaruhi aktivitas di pasar modal. Salah satu peristiwa yang disinyalir dapat menyebabkan perubahan harga serta volume perdagangan pada tahun 2020 adalah kondisi pandemi Covid-19 yang tidak hanya memukul bursa saham global tetapi juga di Indonesia. Gejolak ekonomi yang diakibatkan oleh pandemi Covid-19 telah menghantam Indonesia yang paling tidak memberikan dampak dalam berbagai sektor. Kemungkinan risiko yang dicemaskan oleh investor dan analis pasar modal adalah terjadinya resesi dan krisis ekonomi karena terjadi perlambatan ekonomi. Berbagai bisnis di sektor riil terpukul akibat pandemi Covid-19 sehingga aktivitas bisnis dan produksi banyak mengalami gangguan bahkan sebagian memutuskan berhenti. Dampak dari hal tersebut tentu saja banyak karyawan yang terpaksa dirumahkan sehingga menurunkan daya beli di masyarakat. Gejolak ekonomi akibat Covid19 menjadi salah satu momen bersejarah karena berdampak pada pengelolaan keuangan negara hingga dilakukan perubahan Anggaran Pendapatan dan Belanja Negara (APBN) sebanyak dua kali dan adanya berbagai upaya pemerintah melakukan pemulihan ekonomi nasional. Untuk membuktikan apakah peristiwa tersebut memberikan dampak lebih terhadap kondisi pasar modal Indonesia maka akan dilakukan pengujian kandungan informasi peristiwa tersebut dengan menggunakan studi peristiwa (event study). Nurmasari (2020) membuktikan secara empiris bahwa telah terjadi penurunan harga saham dan peningkatan volume transaksi pada PT. 
Ramayana Lestari Sentosa, Tbk atas perbedaan 31 hari sebelum dan 31 hari sesudah pengumuman kasus pertama Covid19. Penelitian ini dilakukan karena masih minimnya penelitian tentang dampak Covid19 terhadap harga saham dan aktivitas volume perdagangan saham LQ-45. Tolok ukur yang digunakan dalam penelitian ini adalah abnormal return dan trading volume activity. Penelitian terkait event study yang masih memiliki kesenjangan riset juga menjadi alasan mengapa penelitian ini dilakukan.

\section{Tinjauan pustaka \\ Teori sinyal (signaling theory)}

Menurut Fahmi (2012:100), signaling theory adalah teori yang membahas tentang naik turunnya harga di pasar sehingga akan memberikan pengaruh pada keputusan investor sehingga informasi yang terjadi dari kondisi saham suatu perusahaan selalu memberikan efek bagi keputusan investor sebagai pihak yang menangkap sinyal tersebut. Sinyal ini berupa informasi mengenai apa yang sudah dilakukan oleh manajemen untuk merealisasikan keinginan pemilik. Sinyal dapat berupa promosi atau informasi lain yang menyatakan bahwa perusahaan tersebut lebih baik daripada perusahaan lain.

Teori sinyal (signaling theory) merupakan teori yang menjelaskan kepada pihak eksternal yang bisa digunakan untuk mengurangi informasi asimetri. Bagi seorang investor, informasi merupakan hal penting yang harus diketahui sebelum mengambil keputusan investasi. Informasi yang lengkap, relevan, akurat, dan tepat waktu sangat diperlukan oleh investor di pasar modal sebagai alat analisis untuk mengambil keputusan. Teori sinyal (signaling theory) menyatakan bahwa perusahaan yang berkualitas baik dengan sengaja akan memberikan sinyal pada pasar, dengan demikian pasar dapat diharapkan membedakan perusahaan yang berkualitas baik dan berkualitas buruk. Agar sinyal tersebut baik, maka harus dapat ditangkap pasar dengan dipersepsikan baik serta tidak mudah ditiru oleh perusahaan yang memiliki kualitas yang buruk. Informasi yang dipublikasikan sebagai suatu pengumuman akan memberikan sinyal bagi para investor dalam mengambil keputusan investasi. Jika pengumuman akan mengandung nilai positif, maka diharapkan pasar akan bereaksi pada waktu pengumuman tersebut diterima oleh pasar (Choriliyah et al., 2016). Sinyalsinyal dari informasi yang beredar dapat mempengaruhi tindakan yang diambil investor. Reaksi investor tercermin dalam harga saham dan volume perdagangan di seputar perilisan informasi tersebut. Untuk mengetahui ada tidaknya reaksi investor yang berkaitan dengan sinyal-sinyal informasi dari perusahaan dapat menggunakan studi peristiwa (event study).

\section{Harga saham}

Pada aktivitas pasar modal, hal yang paling penting diperhatikan oleh investor dalam melakukan investasi adalah pergerakan harga sahamnya, karena pergerakan tersebut menunjukkan kinerja ataupun prestasi yang sedang dilalui emiten. Apabila kinerja emiten semakin baik, maka keuntungan yang dihasilkan dari operasi usaha akan semakin besar. Pada kondisi ini, harga saham emiten yang bersangkutan cenderung menunjukkan kenaikan. Sebaliknya, apabila kinerja emiten memburuk, maka keuntungan yang dihasilkan dari operasi usaha akan semakin kecil. Pada kondisi ini, harga saham emiten yang bersangkutan akan menunjukkan penurunan. Investor harus menyadari bahwa di samping akan mendapatkan keuntungan dari berinvestasi, tidak menutup kemungkinan jika mereka juga akan mengalami kerugian. Keuntungan dan kerugian tersebut sangat dipengaruhi oleh kemampuan atau keahlian investor dalam menganalisis keadaan harga saham. Informasi tentang perusahaan mana yang akan membawakan keuntungan atau kerugian bagi investor dapat ditinjau dari faktor-faktor yang mempengaruhi pergerakan harga saham, yaitu faktor internal dan faktor eksternal (Agustina dan Sumartio, 2014). 
Harahap (2016) melakukan penelitian yang menguji faktor-faktor yang mempengaruhi harga saham Jakarta Islamic Index, dimana hasil penelitian menunjukkan bahwa pergerakan penjualan, nilai buku, pergerakan rasio utang, pergerakan tingkat suku bunga dan pergerakan harga saham periode sebelumnya mempengaruhi harga saham PT. Aneka Tambang (Persero), Tbk dan PT. Indonesian Satellite Corporation (Persero), Tbk. Terdapat beberapa faktor yang dapat mempengaruhi fluktuasi harga saham di pasar modal, hal ini terjadi karena harga saham dapat dipengaruhi oleh faktor eksternal dari perusahaan maupun faktor internal perusahaan. Menurut Brigham et al. (2010:238), harga saham dipengaruhi oleh beberapa faktor utama yaitu:

1. Faktor internal, diantaranya:

a. Pengumuman tentang pemasaran, produksi, dan penjualan seperti pengiklanan, rincian kontrak, perubahan harga, penarikan produk baru, laporan produksi, laporan keamanan, dan laporan penjualan.

b. Pengumuman pendanaan, seperti pengumuman yang berhubungan dengan ekuitas dan utang.

c. Pengumuman dewan direksi (management board of director announcements) seperti perubahan dan pergantian direktur, manajemen, dan struktur organisasi.

d. Pengumuman pengambilalihan diverifikasi seperti laporan merger investasi, investasi ekuitas, laporan takeover oleh pengakuisisian dan diakuisisi, laporan investasi, dan lainnya.

e. Pengumuman investasi seperti melakukan ekspansi pabrik pengembangan riset dan penutupan usah lainnya.

f. Pengumuman ketenagakerjaan (labour announcements), seperti negosiasi baru, kontrak baru, pemogokan, dan lainnya.

g. Pengumuman laporan keuangan perusahaan, seperti peramalan laba sebelum akhir tahun fiskal dan setelah akhir tahun fiskal, Earnings per Share (EPS), Dividend per Share (DPS), Price Earning Ratio (PER), Net Profit Margin (NPM), Return on Assets (ROA), dan lain-lain.

2. Faktor eksternal, diantaranya:

a. Pengumuman dari pemerintah seperti perubahan suku bunga tabungan dan deposito kurs valuta asing, inflasi, serta berbagai regulasi dan regulasi ekonomi yang dikeluarkan oleh pemerintah.

b. Pengumuman hukum seperti tuntutan terhadap perusahaan atau terhadap manajernya dan tuntutan perusahaan terhadap manajernya.

c. Pengumuman industri sekuritas, seperti laporan pertemuan tahunan insider trading, volume atau harga saham perdagangan pembatasan atau penundaan trading.

\section{Abnormal return}

Menurut Akbar et al. (2019), abnormal return adalah hasil yang tidak sesuai harapan (abnormal) karena adanya ringkasan tentang hasil yang sesungguhnya (return saham) berbeda dengan return yang diharapkan (expected return). Sedangkan menurut Hartono (2013:94), abnormal return merupakan kelebihan dari imbal hasil yang sesungguhnya terjadi (actual return) terhadap imbal hasil normal. Imbal hasil normal merupakan imbal hasil ekspektasi (expected return) atau imbal hasil yang diharapkan oleh investor. Dengan demikian, imbal hasil tidak normal (abnormal return) adalah selisih antara imbal hasil sesungguhnya yang terjadi dengan imbal hasil ekspektasi. Abnormal return dapat dihitung dengan beberapa model yaitu: (1) model rata-rata disesuaikan (meanadjusted model); (2) model pasar (market model); dan (3) model pasar disesuaikan (marketadjusted model).

\section{Aktivitas volume perdagangan (activity trading volume)}

Menurut Akbar et al. (2019), volume perdagangan saham (trading volume activity) yaitu indikator yang digunakan untuk mengukur likuiditas suatu saham. Apabila secara statistik perdagangan saham beberapa 
hari setelah peristiwa terdapat peningkatan dibanding beberapa hari sebelum peristiwa, maka dapat dikatakan bahwa terdapat peningkatan likuiditas perdagangan saham setelah terjadinya suatu peristiwa. Menurut Umam dan Sutanto (2017:186), ada beberapa prinsip dalam penafsiran volume perdagangan, yaitu:

1. Prinsip yang paling utama adalah volume perdagangan sejalan dengan trend. Aktivitas perdagangan akan meningkat pada saat pasar sedang uptrend dan aktivitas perdagangan akan menurun pada saat pasar sedang downtrend. Hal ini berarti volume perdagangan dapat digunakan untuk memprediksi trend pada saat itu. Perdagangan mengukur antusiasme pembeli dan penjual. Pada saat pasar uptrend dengan volume perdagangan yang rendah dapat disebabkan oleh kurangnya penjual dibandingkan dengan antusiasme pembeli. Cepat atau lambat hal ini akan mendorong pasar mencapai harga yang membuat penjual bersedia menjual saham.

2. Aktivitas pembeli dan penjual di pasar modal sangat mempengaruhi harga saham. Misalnya, jika seorang penjual bereaksi terhadap suatu berita buruk kemudian menjual sahamya, hal ini akan menyebabkan harga saham turun.

Harga saham meningkat dan volume perdagangkan yang menurun adalah kondisi tidak normal dan mengindikasikan bahwa trend yang terjadi tidak kuat dan akan mengalami perubahan. Aktivitas seperti ini biasanya merupakan trend menurun (bearish) dan merupakan salah satu hal yang harus diperhitungkan, yaitu volume perdagangan mengukur antusiasme pembeli dan penjual. Pada saat pasar uptrend dengan volume perdagangan yang rendah dapat disebabkan oleh kurangnya penjual dibandingkan dengan antusiasme pembeli. Cepat atau lambat hal ini akan mendorong pasar mencapai harga yang membuat penjual bersedia menjual saham.

\section{Penelitian terkait event study}

Hartawan et al. (2015) dalam penelitian yang telah dilakukan untuk menguji perubahan volume perdagangan saham dan abnormal return sebelum dan sesudah Pemilu Legislatif pada tanggal 9 April 2014 menyimpulkan bahwa tidak terdapat perbedaan yang signifikan rata-rata aktivitas volume perdagangan saham dan rata-rata abnormal return pada sektor-sektor industri sebelum dan sesudah peristiwa pemilihan umum legislatif tahun 2014. Hal ini merefleksikan bahwa peristiwa tersebut merupakan peristiwa yang sudah dapat diantisipasi pelaku pasar dan pelaku pasar lebih memfokuskan keputusan investasinya pada kinerja perusahaan.

Kusumayanti dan Suarjaya (2018) menemukan bahwa peristiwa pengumuman kemenangan Donald Trump dalam Pemilihan Presiden Amerika Serikat tahun 2016 menimbulkan reaksi pasar. Kusumayanti dan Suarjaya (2018) menunjukkan bahwa reaksi pasar dapat dilihat dari adanya abnormal return yang signifikan, yaitu pada $\mathrm{H}+1, \mathrm{H}+3, \mathrm{H}+4$ dan $\mathrm{H}+5$. Kusumayanti dan Suarjaya (2018) menemukan bahwa kecepatan reaksi pasar modal terhadap peristiwa tersebut bereaksi cepat karena terdapat abormal return yang signifikan pada satu hari $(\mathrm{H}+1)$ setelah peristiwa namun abnormal return muncul kembali pada $\mathrm{H}+3, \mathrm{H}+4$ dan $\mathrm{H}+5$ menunjukkan bahwa pasar tidak efisien, karena reaksi terjadi berkepanjangan. Diniar dan Kiryanto (2015) menganalisis dampak Pemilu Presiden Jokowi terhadap return saham. Diniar dan Kiryanto (2015) menunjukkan bahwa pemilihan presiden tanggal 9 Juli 2014 memberikan perubahan terhadap abnormal return saham dan TVA yang signifikan pada 5 hari sebelum dan sesudah pemilu. Diniar dan Kiryanto (2015) menemukan bahwa sesudah pemilihan presiden abnormal return saham lebih rendah dibanding sebelum pemilihan presiden sehingga jika dilihat berdasarkan reaksi per hari dari investor selama 5 hari sebelum hingga 5 hari sesudah pemilu pemilihan presiden, diperoleh reaksi yang signifikan terjadi pada 4 hari dan 2 hari sebelum 
pemilihan presiden yang merupakan reaksi positif dari investor.

Reaksi investor terhadap isu pencabutan Domestic Market Obligation (DMO) dan melemahnya kurs Rupiah telah diteliti oleh Rofiah et al. (2019). Berdasarkan sampel perusahaan tambang batubara yang terdaftar di BEI, Rofiah et al. (2019) menunjukkan bukti empiris bahwa terdapat perbedaan abnormal return sebelum dan sesudah isu pencabutan DMO, sedangkan terkait trading volume activity tidak terdapat perbedaan abnormal return. Selain itu, Rofiah et al. (2019) juga memberikan bukti empiris bahwa terdapat perbedaan rata-rata trading volume activity sebelum dan sesudah melemahnya kurs Rupiah. Penelitian event study oleh Haryanto (2020) menunjukkan bahwa pandemi Covid-19 juga berdampak secara nyata terhadap fluktuasi nilai tukar Rp/US\$ dan fluktuasi IHSG. Berdasarkan rumusan masalah, landasan teori, dan kerangka konseptual yang telah disajikan di atas maka hipotesis yang diajukan adalah:

$\mathrm{H}_{1}$ : Diduga terdapat perbedaan rata-rata abnormal return pada saham LQ-45 saat sebelum dan sesudah peristiwa pengumuman kasus pertama Covid-19 di Indonesia.

$\mathrm{H}_{2}$ : Diduga terdapat perbedaan rata-rata trading volume activity pada saham LQ-45 saat sebelum dan sesudah peristiwa pengumuman kasus pertama Covid-19 di Indonesia.

\section{Metode penelitian}

Menurut Sugiyono (2016:149), sampel adalah bagian dari jumlah karakteristik yang dimiliki oleh populasi. Jumlah sampel dalam penelitian ini adalah sama dengan jumlah populasi yaitu sebanyak 45 perusahaan. Adapun kriteria yang digunakan dalam memilih sampel yaitu:

1. Emiten yang tergabung dalam indeks LQ-45 di Bursa Efek Indonesia (BEI) selama periode jendela yaitu dimulai pada 4 Februari 2020 hingga 1 April 2020.

2. Emiten tersebut tidak melakukan corporate action lainnya seperti pengumuman right issue, merger, akuisisi perusahaan, pembagian dividen, stock split, dan lain sebagainya selama periode penelitian yaitu pada periode estimasi dan periode jendela.

Periode jendela yang digunakan 60 hari, yaitu 30 hari sebelum peristiwa pengumuman kasus pertama pasien Covid19 di Indonesia (t-30) dan 30 hari setelah peristiwa pengumuman kasus pertama pasien Covid-19 di Indonesia $(\mathrm{t}+30)$. Penentuan periode jendela ini diharapkan pasar bereaksi secara penuh terhadap peristiwa yang terjadi serta dapat dilihat kecepatan reaksi pasar terhadap peristiwa tersebut.

Konsisten dengan Rofiah et al. (2019), penelitian ini menerapkan langkah-langkah berikut dalam menghitung variabel abnormal return.

1. Menghitung abnormal return dengan persamaan berikut.

$$
\mathrm{AR}_{\mathrm{it}}=\mathrm{R}_{\mathrm{it}}-\mathrm{E}\left[\mathrm{R}_{\mathrm{it}}\right]
$$

$\mathrm{AR}_{\mathrm{it}}$ adalah abnormal return saham i pada periode peristiwa $t, \mathrm{R}_{\mathrm{it}}$ adalah return realisasian saham $i$ pada periode peristiwa $t$, dan $E\left[R_{i t}\right]$ adalah return ekspektasian saham i pada periode peristiwa t.

2. Menghitung return ekspektasian dengan persamaan berikut.

$$
\mathrm{E}\left(\mathrm{R}_{\mathrm{it}}\right)=\mathrm{R}_{\mathrm{Mt}}
$$

$\mathrm{E}\left(\mathrm{R}_{\mathrm{it}}\right)$ adalah return ekspektasian sekuritas ke-i pada saat periode ke-t, sedangkan $\mathrm{R}_{\mathrm{mt}}$ adalah return pasar (market return) yang dihitung dengan rumus berikut.

$\mathrm{R}_{\mathrm{mt}}=\frac{\text { Indeks LQ-45 } \mathrm{t} \text { - Indeks LQ-45 } \mathrm{t}_{\mathrm{t}-1}}{\text { Indeks LQ-45 } \mathrm{t}-1}$

$\mathrm{R}_{\mathrm{mt}}$ adalah return pasar periode peristiwa ke t, Indeks LQ-45 ${ }_{t}$ adalah indeks pasar LQ-45 pada periode ke t (sekarang), dan Indeks LQ-45 ${ }_{\mathrm{t}-1}$ adalah indeks pasar LQ45 pada periode $\mathrm{t}-1$ (periode sebelumnya). Langkah selanjutnya adalah menghitung return realisasian dengan rumus berikut.

$$
\mathrm{R}_{\mathrm{it}}=\frac{\mathrm{P}_{\mathrm{t}}-\mathrm{P}_{\mathrm{t}-1}}{\mathrm{P}_{\mathrm{t}-1}}
$$


$\mathrm{R}_{\text {it }}$ adalah return saham i pada periode $t$, $\mathrm{P}_{\mathrm{t}}$ adalah harga saham i pada periode $t$, dan $\mathrm{P}_{\mathrm{t}-1}$ adalah harga saham $\mathrm{i}$ pada periode $\mathrm{t}-1$.

3. Menghitung Average Abnormal Return (AAR) dengan rumus berikut.

$$
\mathrm{AAR}_{\mathrm{t}}=\frac{\sum_{\mathrm{i}=1}^{\mathrm{n}} \mathrm{AR}_{\mathrm{i}, \mathrm{t}}}{\mathrm{n}}
$$

$\mathrm{AAR}_{\mathrm{t}}$ adalah average abnormal return pada tanggal ke $\mathrm{t}, \mathrm{AR}_{\mathrm{i}, \mathrm{t}}$ adalah abnormal return sekuritas ke-i pada hari ke-t, dan $n$ adalah jumlah sekuritas.

Konsisten dengan Hartawan et al. (2015), penelitian ini menerapkan langkahlangkah berikut dalam menghitung variabel Trading Volume Activity (TVA).

1. Menghitung Trading Volume Activity (TVA) masing-masing sekuritas dengan rumus berikut.

$$
\text { TVA }=\frac{\sum \text { saham yang diperdagangkan }}{\sum \text { saham yang beredar }}
$$

2. Menghitung rata-rata Trading Volume Activity (TVA) seluruh saham yang dijadikan sampel.

$$
\operatorname{ATVA}_{\mathrm{t}}=\frac{\sum_{\mathrm{t}=1}^{\mathrm{n}} \mathrm{TVA}_{\mathrm{i}, \mathrm{t}}}{\mathrm{n}}
$$

$\mathrm{TVA}_{\mathrm{i}, \mathrm{t}}$ adalah trading volume activity sekuritas ke-i pada hari ke-t, dan $n$ adalah jumlah sekuritas.
Metode analisis data yang digunakan adalah model analisis uji beda t-test. Pertama-tama setelah data yang terkumpul akan dianalisis secara bertahap melalui statistik deskriptif kemudian dilakukan pengujian statistik melalui uji distribusi normal dengan menggunakan uji KolmogorovSmirnov. Selanjutnya, pengujian hipotesis setiap variabel penelitian menggunakan uji analisis paired sampel t-test apabila data yang terkumpul terdistribusi secara normal dan model uji analisis Wilcoxon Signed Rank apabila data tidak terdistribusi secara normal. Penjelasan tahapan-tahapan pengujian disajikan sebagai berikut.

1. Uji analisis deskriptif.

2. Uji normalitas dengan uji KolmogorovSmirnov karena uji ini lebih peka mendeteksi normalitas dibandingkan metode grafik. Sampel terdistribusi normal apabila asymptotic sig $>$ tingkat keyakinan yang digunakan dalam pengujian ini yaitu $95 \%$ atau $\alpha=5 \%$. Sebaliknya, dikatakan tidak normal apabila asymptotic sig < tingkat keyakinan $\alpha=5 \%$.

3. Uji hipotesis dimana dalam penelitian ini uji paired sample t-test digunakan untuk menganalisis perbedaan abnormal return dan trading volume activity sebelum dan setelah peristiwa pengumuman kasus pertama Covid-19 di Indonesia. Gambar 1 menunjukkan model penelitian yang menyajikan variabel yang diteliti.

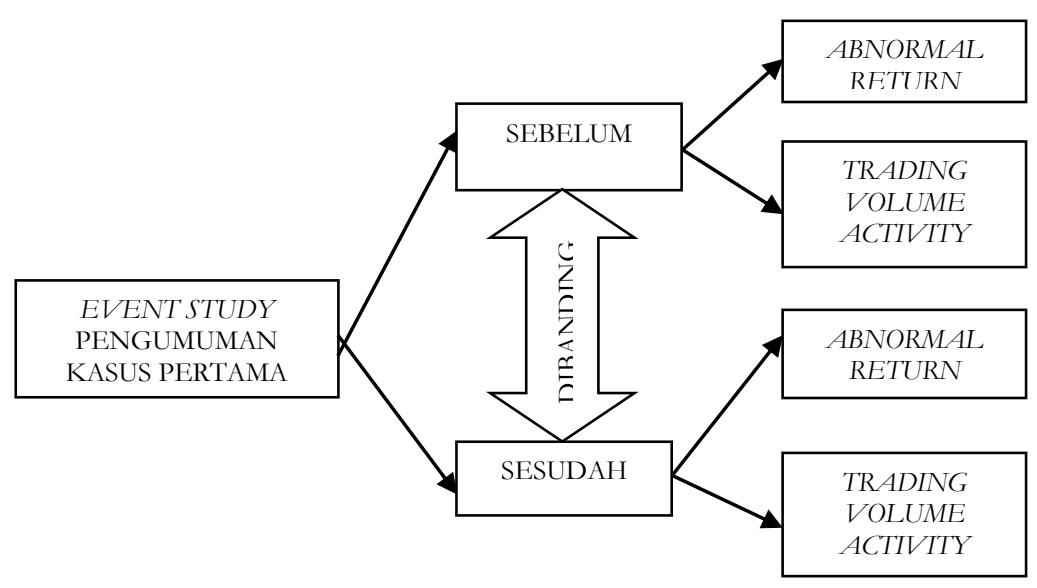

Gambar 1. Model penelitian 


\section{Hasil penelitian dan pembahasan \\ Hasil penelitian \\ Tabel 1 menyajikan hasil analisis statistik deskriptif variabel-variabel dalam penelitian}

ini yang terdiri dari variabel abnormal return dan trading volume activity dengan melihat jumlah sampel $(\mathrm{N})$, rata-rata sampel (mean), nilai maksimum serta standar deviasi $(\sigma)$.

Tabel 1. Deskriptif variabel penelitian

\begin{tabular}{lcrrrr}
\hline & N & \multicolumn{1}{c}{ Minimum } & Maximum & \multicolumn{1}{c}{ Mean } & \multicolumn{1}{c}{ Std. Deviation } \\
\hline AARsebelum & 45 & $-0,0069579$ & 0,0045870 & $-0,000502614$ & 0,0023170681 \\
AARsesudah & 45 & $-0,0160002$ & 0,0057153 & $-0,003177844$ & 0,0055143385 \\
ATVAsebelum & 45 & 0,0001349 & 0,0022149 & 0,000593616 & 0,0004321318 \\
ATVAsesudah & 45 & 0,0002098 & 0,0036278 & 0,001024534 & 0,0007376951 \\
Valid N (listwise) & 45 & & & & \\
\hline
\end{tabular}

Penelitian ini melakukan uji normalitas dengan menggunakan one sample KolmogorovSmirnov test. Dasar pengambilan keputusannya yaitu apabila signifikan hitung $>0,05$ maka data berdistribusi normal demikian sebaliknya bila signifikan hitung $<$ 0,05 data tidak berdistribusi normal (Ghozali, 2011:173). Tabel 2 menunjukkan bahwa variabel rata-rata abnormal return sebelum peristiwa pengumuman kasus pertama pasien Covid-19 memiliki nilai asymp. sig (2-tailed) sebesar 0.997 dan untuk variabel rata-rata abnormal return setelah peristiwa pengumuman kasus pertama pasien Covid-19 memiliki nilai sebesar 0.760. Oleh karena nilainya lebih dari 0.05 maka dapat disimpulkan bahwa kedua variabel tersebut telah terdistribusi secara normal. Variabel rata-rata trading volume activity sebelum peristiwa pengumuman kasus pertama pasien Covid-19 memiliki nilai 0,151 dan setelah peristiwa pengumuman kasus pertama pasien Covid19 memiliki nilai sebesar 0,161 sehingga dapat ditarik kesimpulan bahwa kedua variabel tersebut juga terdistribusi secara normal karena nilai lebih dari 0.05. Uji hipotesis yang dilakukan dalam penelitian ini menggunakan uji paired sample t-test. Uji ini dilakukan untuk membandingkan dua variabel yang saling berhubungan serta dilakukan apabila data terdistribusi secara normal.

Tabel 2. Uji normalitas data

\begin{tabular}{llrrrr}
\hline & & AARsebelum & AARsesudah & ATVAsebelum & ATVAsesudah \\
\hline N & & \multicolumn{1}{c}{45} & \multicolumn{1}{c}{45} & 45 \\
Normal Parameters & Mean & $-0,000503$ & $-0,003178$ & 0,000594 & 0,001025 \\
& Std. Deviation & 0,002317 & 0,005514 & 0,000432 & 0,000738 \\
Most Extreme Differences & Absolute & 0,060 & 0,100 & 0,169 & 0,167 \\
& Positive & 0,055 & 0,071 & 0,169 & 0,167 \\
& Negative & $-0,060$ & $-0,100$ & $-0,144$ & $-0,135$ \\
Kolmogorov-Smirnov $Z$ & & 0,403 & 0,670 & 1,136 & 1,122 \\
Asymp. Sig. (2-tailed) & & 0,997 & 0,760 & 0,151 & 0,161 \\
\hline
\end{tabular}

Tabel 3 menyajikan hasil uji korelasi atau hubungan antar kedua data atau hubungan variabel antara abnormal return sebelum peristiwa pengumuman kasus pertama pasien Covid-19 di Indonesia dan abnormal return sesudah peristiwa pengumuman kasus pertama pasien Covid-19 di Indonesia. Tabel 3 menunjukkan bahwa nilai koefisien korelasi (correlation) sebesar -0,256 dengan nilai signifikansi (sig.) sebesar 0,090. Oleh karena nilai sig. $0,090>$ probabilitas 0,05 , maka dapat dikatakan bahwa tidak ada hubungan antara abnormal return sebelum peristiwa pengumuman kasus pertama pasien Covid-19 di Indonesia dan abnormal return sesudah peristiwa pengumuman kasus pertama pasien Covid-19 di Indonesia. 
Tabel 5. Uji paired samples correlations abnormal return

\begin{tabular}{llcc}
\hline & N & Correlation & Sig \\
\hline AARsebelum-AARsesudah & 45 & $-0,256$ & 0,090 \\
\hline
\end{tabular}

Tabel 4 menyajikan hasil pengujian hipotesis uji beda rata-rata abnormal return sebelum peristiwa pengumuman kasus pertama pasien Covid-19 di Indonesia dan abnormal return sesudah peristiwa pengumuman kasus pertama pasien Covid19 di Indonesia. Hasil analisis menunjukkan bahwa nilai sig. (2-tailed) sebesar $0,008<0.5$ sehingga dapat disimpulkan bahwa hipotesis pertama diterima yang artinya ada perbedaan rata-rata abnormal return sebelum peristiwa pengumuman kasus pertama pasien Covid19 di Indonesia dan abnormal return sesudah peristiwa pengumuman kasus pertama pasien Covid-19 di Indonesia.

Tabel 4. Uji paired samples t-test abnormal return

\begin{tabular}{|c|c|c|c|c|c|c|c|c|}
\hline & \multicolumn{5}{|c|}{ Paired Differences } & \multirow{3}{*}{$\mathbf{t}$} & \multirow{3}{*}{ df } & \multirow{3}{*}{ Sig. (2-tailed) } \\
\hline & \multirow[t]{2}{*}{ Mean } & \multirow[t]{2}{*}{$\begin{array}{c}\text { Std. } \\
\text { Deviation }\end{array}$} & \multirow[t]{2}{*}{$\begin{array}{l}\text { Std. Error } \\
\text { Mean }\end{array}$} & \multicolumn{2}{|c|}{$\begin{array}{c}95 \% \text { Confidence } \\
\text { Interval of the } \\
\text { Difference }\end{array}$} & & & \\
\hline & & & & Lower & Upper & & & \\
\hline AARsebelum-AARsesudah & $-0,002675$ & 0,006505 & 0,000970 & 0,000721 & 0,004630 & 2,759 & 44 & 0,008 \\
\hline
\end{tabular}

Tabel 5 menyajikan hasil uji korelasi atau hubungan antar kedua data atau hubungan variabel antara trading volume activity sebelum peristiwa pengumuman kasus pertama pasien Covid-19 di Indonesia dan trading volume activity sesudah peristiwa pengumuman kasus pertama pasien Covid19 di Indonesia. Tabel 5 menunjukkan bahwa nilai koefisien korelasi (correlation) sebesar 0,835 dengan nilai signifikansi (sig.) sebesar 0,000. Oleh karena nilai sig. 0,000 > probabilitas 0,05, maka dapat dikatakan bahwa ada hubungan antara trading volume activity sebelum peristiwa pengumuman kasus pertama pasien Covid-19 di Indonesia dan trading volume activity sesudah peristiwa pengumuman kasus pertama pasien Covid19 di Indonesia.

Tabel 5. Uji paired samples correlations Trading Volume Activity

\begin{tabular}{llcc}
\hline & $\mathbf{N}$ & Correlation & Sig \\
\hline ATVAsebelum-ATVAsesudah & 45 & 0,835 & 0,000 \\
\hline
\end{tabular}

Tabel 6 menunjukkan hasil pengujian hipotesis uji beda rata-rata trading volume activity sebelum peristiwa pengumuman kasus pertama pasien Covid-19 di Indonesia dan trading volume activity sesudah peristiwa pengumuman kasus pertama pasien Covid19 di Indonesia memperoleh hasil Sig. (2tailed) sebesar $0,000<0.5$. Hasil ini menunjukkan bahwa hipotesis kedua diterima yang artinya ada perbedaan rata-rata trading volume activity sebelum peristiwa pengumuman kasus pertama pasien Covid19 di Indonesia dan trading volume activity sesudah peristiwa pengumuman kasus pertama pasien Covid-19 di Indonesia.

Tabel 6. Hasil uji paired samples t-test Trading Volume Activity

\begin{tabular}{|c|c|c|c|c|c|c|c|c|}
\hline (2) & \multicolumn{5}{|c|}{ Paired Differences } & \multirow{3}{*}{$\mathrm{t}$} & \multirow{3}{*}{ df } & \multirow{3}{*}{ Sig. (2-tailed) } \\
\hline & \multirow[t]{2}{*}{ Mean } & \multirow[t]{2}{*}{$\begin{array}{c}\text { Std. } \\
\text { Deviation }\end{array}$} & \multirow[t]{2}{*}{$\begin{array}{l}\text { Std. Error } \\
\text { Mean }\end{array}$} & \multicolumn{2}{|c|}{$\begin{array}{c}95 \% \text { Confidence } \\
\text { Interval of the } \\
\text { Difference }\end{array}$} & & & \\
\hline & & & & Lower & Upper & & & \\
\hline ATVAsebelum-ATVAsesudah & $-0,000431$ & 0,000445 & 0,000066 & $-0,000565$ & $-0,000297$ & $-6,492$ & 44 & 0,000 \\
\hline
\end{tabular}

\section{Pembahasan}

Hasil analisis menunjukkan bahwa hipotesis pertama $\left(\mathrm{H}_{1}\right)$ dapat diterima, yang artinya bahwa reaksi pasar modal yang diukur dengan menggunakan abnormal return memiliki perbedaan signifikan pada periode sebelum dan sesudah pengumuman kasus pertama Covid-19. Rata-rata abnormal return 
harga saham keseluruhan sebelum dan sesudah pengumuman kasus pertama Covid19 di Indonesia menunjukkan bahwa terdapat 30 perusahaan yang mengalami penurunan harga saham dan 15 perusahaan mengalami kenaikan harga saham sesudah pengumuman kasus Covid-19 di Indonesia. Hasil ini sejalan dengan penelitian yang dilakukan oleh Nurmasari (2020) yang meneliti dampak Covid-19 terhadap perubahan harga saham dan volume transaksi di PT. Ramayana Lestari, Tbk bahwa terdapat perbedaan nilai rata-rata harga saham pada PT Ramayana Lestari, Tbk. Hasil penelitian ini juga sejalan dengan event study dari Sidqi dan Prabawani (2017) yang menemukan bahwa terdapat perbedaan signifikan antara harga saham sebelum dan sesudah stock split dimana rata-rata harga saham keseluruhan sebelum dan sesudah stock split pada tahun 2010 sampai 2015 menunjukkan bahwa terdapat 28 perusahaan yang mengalami kenaikan harga saham setelah dilakukan stock split sedangkan 14 perusahaan lainnya mengalami penurunan harga saham setelah dilakukan stock split.

Hasil analisis menunjukkan bahwa hipotesis pertama $\left(\mathrm{H}_{2}\right)$ dapat diterima, yang artinya bahwa reaksi pasar modal yang diukur dengan menggunakan trading volume activity memiliki perbedaan signifikan pada periode sebelum dan sesudah pengumuman kasus pertama Covid-19. Hasil ini sejalan dengan penelitian yang dilakukan oleh Nurmasari (2020) yang meneliti dampak Covid-19 terhadap perubahan harga saham dan volume transaksi di PT Ramayana Lestari, Tbk yang menyatakan pada PT. Ramayana Lestari Sentosa, Tbk mengalami peningkatan volume transaksi saham yang signifikan karena adanya kasus yang diakibatkan oleh Covid-19. Peningkatan volume transaksi saham ini terjadi karena meningkatnya aktivitas jual beli saham pada PT. Ramayana Lestari Sentosa, Tbk.

\section{Kesimpulan dan saran} Kesimpulan

Berdasarkan hasil analisis data dan pembahasan maka dapat ditarik kesimpulan sebagai berikut:
1. Terdapat perbedaan signifikan antara abnormal return sebelum dan sesudah pengumuman kasus pertama pasien Covid-19 di Indonesia. Hal ini dibuktikan dengan nilai sig. (2-tailed) sebesar $0,008<0.5$ dengan nilai mean sebelum dan sesudah sebesar 0,0026752293 didapatkan nilai t sebesar 2,759 . Nilai t yang positif menunjukkan bahwa rata-rata abnormal return sebelum lebih besar dari nilai rata-rata abnormal return sesudah peristiwa. Hasil ini mengimplikasikan bahwa pasar memberikan sinyal yang kurang baik pada investor setelah peristiwa pengumuman kasus pertama pasien Covid-19 di Indonesia sehingga cenderung menyebabkan harga saham perusahaan LQ-45 mengalami penurunan.

2. Terdapat perbedaan signifikan antara trading volume activity sebelum dan sesudah pengumuman kasus pertama pasien Covid-19 di Indonesia. Hal ini dibuktikan dengan nilai sig. (2-tailed) sebesar $0,000<0.5$ dengan nilai mean sebelum dan sesudah sebesar 0,0004309178 didapatkan nilai t sebesar -6,492. Nilai $t$ yang negatif menunjukkan bahwa rata-rata trading volume activity setelah lebih besar dari nilai rata-rata trading volume activity sebelum peristiwa. Hasil ini juga mengimplikasikan bahwa pasar memberikan sinyal yang kurang baik pada investor setelah pengumuman kasus pertama pasien Covid-19 di Indonesia sehingga cenderung mengakibatkan investor melakukan penjualan atas saham perusahaan LQ45.

\section{Saran}

Keterbatasan penelitian ini adalah tidak melihat perbedaan abnormal return dan trading volume activity di sekitar tanggal peristiwa pengumuman dan hanya menggunakan variabel abnormal return dan trading volume activity sehingga saran untuk penelitian berikutnya adalah menambah variabel lain selain abnormal return dan trading 
volume activity untuk menggambarkan reaksi pada pasar modal, seperti variabel security return variability. Penelitian ini juga menyarankan agar meneliti bagaimana perbedaan abnormal return dan trading volume avtivity sebelum dan saat peristiwa pengumuman kasus pertama pasien Covid19 di Indonesia.

\section{Ketersediaan data}

Data penelitian ini dapat diakses secara terbuka pada dokumen pendukung artikel (supplementary file).

\section{Daftar pustaka}

Akbar, E. P., Saerang, I. S., \& Maramis, J. B. (2019). Reaksi pasar modal terhadap pengumuman kemenangan Presiden Joko Widodo berdasarkan Keputusan KPU Pemilu Periode 2019-2024 (Studi pada perusahaan BUMN yang terdaftar di BEI). Jurnal Ilmiah Manajemen Bisnis dan Inovasi, 6(2), 123-131. https://doi.org/10.35794/imbi.v6i2.26169

Agustina, \& Sumartio, F. (2014). Analisa faktor-faktor yang mempengaruhi pergerakan harga saham pada perusahaan pertambangan. Jurnal Wira Ekonomi Mikroskil, $\quad 4(1), \quad$ 51-61. https://www.mikroskil.ac.id/ejurnal/index.php/ jwem/article/view/213

Arde, M. H. D., \& Kesuma, K. W. (2017). Studi peristiwa Tragedi Sarinah terhadap pasar modal Indonesia. E-Jurnal Manajemen, 6(6), 3080-3110. https://ojs.unud.ac.id/index.php/Manajemen/ar ticle/view/29882

Brigham, E. F., Houston, J. F., \& Yulianto, A. A. (2010). Dasar-dasar Manajemen Keuangan, Buku I, Edisi 11. Jakarta: Salemba Empat.

Choriliyah, S., Sutanto, H. A., \& Hidayat, D. S. (2016). Reaksi pasar modal terhadap penurunan harga Bahan Bakar Minyak (BBM) atas saham Sektor Industri Transportasi di Bursa Efek Indonesia. Journal of Economic Education, 5(1), 1-10. https://journal.unnes.ac.id/sju/index.php/jeec/ article/view/13011

Diniar, A. H., \& Kiryanto. (2015). Analisis dampak Pemilu Presiden Jokowi terhadap return saham (Studi kasus Saham LQ-45 di Bursa Efek Indonesia). Jurnal Akuntansi Indonesia, 4(2), 97-107. http://dx.doi.org/10.30659/jai.4.2.97-108

Fahmi, I. (2012). Pengantar manajemen keuangan: Teori dan soal jawab. Bandung: Alfabeta.

Ghozali, I. (2011). Aplikasi analisis multivariate dengan program SPSS. Semarang: Badan Penerbit Universitas Diponegoro.

Harahap, D. (2016). Analisis faktor-faktor yang mempengaruhi harga saham Jakarta Islamic Index (JII). Journal Analytica Islamica, 5(2), 342-
367.

http://jurnal.uinsu.ac.id/index.php/analytica/art icle/view/492

Hartawan, I. M. W., Adiputra, I. M. P., \& Darmawan, N. A. S. (2015). Analisis perubahan volume perdagangan saham dan abnormal return sebelum dan sesudah Pemilu Legislatif 9 April 2014 (Event study pada sektor-sektor industri di Bursa Efek Indonesia). Jurnal Ilmiah Mahasiswa Akuntansi Undiksha, 3(1), 1-11. https://ejournal.undiksha.ac.id/index.php/S1ak $\angle$ article/view/4609

Hartono, J. (2013). Teori portfolio dan analisis investasi, Edisi 8. Yogyakarta: BPFE.

Haryanto. (2020). Dampak Covid-19 terhadap pergerakan nilai tukar Rupiah dan Indeks Harga Saham Gabungan (IHSG). The Indonesian Journal of Development Planning, 4(2), 151-165. https://doi.org/10.36574/ipp.v4i2.114

Kusumayanti, K. R., \& Suarjaya, A. A. G. (2018). Reaksi pasar modal Indonesia terhadap pengumuman kemenangan Donald Trump dalam pilpres Amerika Serikat 2016. E-Jurnal Manajemen, 7(4), 1713-1741.

https://doi.org/10.24843/EJMUNUD.2018.v07 .i04.p01

Nurmasari, I. (2020). Dampak Covid-19 terhadap perubahan harga saham dan volume transaksi (Studi kasus pada PT Ramayana Lestari Sentosa, Tbk). Jurnal Sekuritas, 3(3), 230-236. http://dx.doi.org/10.32493/skt.v3i3.5022

Rofiah, S., Maslichah, \& Mawardi, M. C. (2019). Reaksi investor terhadap isu pencabutan DMO dan melemahnya kurs Rupiah (Event study pada perusahaan tambang batu bara yang terdaftar di BEI). Jurnal Ilmiah Riset Akuntansi, 8(9), 20-42. http://riset.unisma.ac.id/index.php/ira/article/v iew/4259

Sidqi, F. I., \& Prabawani, B. (2017). Analisis harga saham dan volume perdagangan saham sebelum dan sesudah melakukan stock split (Studi empiris pada perusahaan go public periode 2010-2015). Jurnal Ilmu Administrasi Bisnis, 6(1), 44-54. https://ejournal3.undip.ac.id/index.php/jiab/art icle/view/14501

Sugiyono. (2016). Metode penelitian manajemen. Bandung: CV. Alfabeta.

Toin, D. R. Y., \& Sutrisno. (2015). Pengaruh faktor internal dan eksternal terhadap harga saham industri perdagangan eceran di Bursa Efek Indonesia. Jurnal Ilmiah Among Makarti, 8(16), 12-22. https://jurnal.stieama.ac.id/index.php/ama/artic le/view/118

Umam, K., \& Sutanto, H. (2017). Manajemen investasi. Bandung: Pustaka Setia.

Utomo, V. J., \& Herlambang, L. (2015). Efek hari libur Lebaran pada emiten yang terdaftar dalam ISSI periode 2011-2013. Jurnal Ekonomi Syariah Ekonomi dan Terapan, 2(5), 372-386. http://dx.doi.org/10.20473/vol2iss20155pp372$\underline{386}$ 